\title{
Flexible and robust strategies for waste management in Sweden
}

\author{
Göran Finnveden ${ }^{\mathrm{a}, *}$, Anna Björklund ${ }^{\mathrm{a}}$, Marcus Carlsson Reich ${ }^{\mathrm{b}}$, \\ Ola Eriksson ${ }^{\mathrm{c}}$, Adrienne Sörbom ${ }^{\mathrm{d}}$ \\ ${ }^{a}$ Division of Environmental Strategies Research - fms, Royal Institute of Technology, SE-100 44 Stockholm, Sweden \\ ${ }^{\mathrm{b}}$ Swedish Environmental Protection Agency, SE-106 48 Stockholm, Sweden \\ ${ }^{c}$ Technology and Built Environment, University of Gävle, SE-801 76 Gävle, Sweden \\ d Department of Sociology, Stockholm University, SE-106 91 Stockholm, Sweden
}

Accepted 16 February 2007

Available online 6 April 2007

\begin{abstract}
Treatment of solid waste continues to be on the political agenda. Waste disposal issues are often viewed from an environmental perspective, but economic and social aspects also need to be considered when deciding on waste strategies and policy instruments. The aim of this paper is to suggest flexible and robust strategies for waste management in Sweden, and to discuss different policy instruments. Emphasis is on environmental aspects, but social and economic aspects are also considered. The results show that most waste treatment methods have a role to play in a robust and flexible integrated waste management system, and that the waste hierarchy is valid as a rule of thumb from an environmental perspective. A review of social aspects shows that there is a general willingness among people to source separate wastes. A package of policy instruments can include landfill tax, an incineration tax which is differentiated with respect to the content of fossil fuels and a weight based incineration tax, as well as support to the use of biogas and recycled materials.
\end{abstract}

(C) 2007 Elsevier Ltd. All rights reserved.

\section{Introduction}

Treatment of solid waste continues to be a topic on the agenda (Formas, 2004), and it is something that is important and sensitive to people in all cultures (Åkesson, 2004). This may be one reason for the recurring debates on how waste should be managed in Sweden and in many other countries.

Waste disposal issues are often viewed from an environmental perspective, and it may be interesting to consider the proportion of the total environmental impact caused by waste in Sweden. Although the exact proportion is difficult to determine, since it depends on the environmental problems considered and the boundaries set for the waste system, several studies however indicate that waste problems represent one or a few percent of Sweden's total environmental burdens (Finnveden et al., 2000; Sundqvist et al.,

\footnotetext{
* Corresponding author. Tel.: +468790 7318; fax: +4687908580.

E-mail address: goran.finnveden@infra.kth.se (G. Finnveden).
}

2002b; Palm et al., 2002). In the case of specific emissions, however, waste can be responsible for a larger share. Overall, therefore, waste problems are less serious than those caused by, e.g., housing, energy supply, food production and traffic. Nonetheless, appropriate waste management can still make a substantial contribution to the attainment of certain environmental targets (Finnveden et al., 2000).

In economic terms, waste management is of interest not only to the waste sector. For instance, $10-15 \%$ of municipal district heating in Sweden is currently supplied by waste incineration, and this fraction is expected to increase considerably in the near future (Eriksson, 2004). Electricity producers are also beginning to express an interest in waste as a fuel. For the recycling industry, waste is the actual raw material on which operations are based. Decisions and investment in the waste sector can have long-term consequences. For example, a waste incineration boiler is a large and long-term investment. However, over the last years waste politics have undergone significant changes, both in Sweden and internationally, and further changes can be 
expected. The markets involved have also changed, for example the electricity market, where long-term development is unpredictable and uncertain.

The combination of long-term decisions, uncertainties about the future, and the inevitable emotional aspects of waste issues, creates a need for flexible and robust waste management. By flexible, we mean solutions that can be adapted to changes arising in the sector. By robust, we mean solutions and strategies that are reasonably appropriate in various conceivable future scenarios, but also reasonably appropriate with respect to the environment and the economy, as well as being acceptable to society. For sustainability in the longer term, a solution must be acceptable in all dimensions of sustainable development.

The aim of this paper is to suggest flexible and robust strategies for solid waste management in Sweden. Its content is based mainly on results from a research project of several years, but complemented when necessary with reviews of other studies in the field. Emphasis of the project was on the environmental aspect, but economic and social aspects were also covered. The results for different aspects of waste management are briefly summarised. Based on these, the implications of strategies and policy instruments are discussed.

\section{Environmental aspects of various waste treatment methods}

A number of studies have been carried out to compare various waste treatment methods. In addition, several reviews have been published comparing the results of different studies (e.g., Finnveden and Ekvall, 1998; Ekvall and Finnveden, 2000; Sundqvist et al., 2002a,b; Björklund and Finnveden, 2005; Profu, 2004). One of these reviews (Sundqvist et al., 2002b) summarised the system studies funded by the Swedish Energy Agency in the research programme Energy From Waste. Some of the conclusions of the review were as follows:

Landfilling waste that could otherwise be incinerated with energy recovery, ${ }^{1}$ biodigested, composted, or recycled is generally unfavourable, both from an environmental and an economic perspective.

In a comparison of biodigestion and incineration of easily degradable household waste, both alternatives have advantages and disadvantages and neither alternative is clearly environmentally better than the other.

Composting (windrow) of easily degradable waste has almost no environmental benefits compared to incineration with energy recovery.

Recycling of materials is generally environmentally better than incineration. This conclusion is based on efficient waste collection.

\footnotetext{
${ }^{1}$ Incineration of municipal solid waste in Sweden is always constructed with energy recovery, mostly as district heating, sometimes also with power generation.
}

In later studies, we reviewed Life Cycle Assessments comparing recycling with incineration and/or landfilling (Björklund and Finnveden, 2005). The review focused on total energy utilisation and emissions of greenhouse gases, as these were the only parameters that were included in all of the reviewed studies. Although this limited the scope of the review, energy use often tends to correlate with other important emissions. The review was also limited to recyclable materials in household waste. The benefit of using LCA in analyzing waste management systems is that it provides a comprehensive view of the processes and impacts involved. Waste management is in itself a large and complex system that is difficult to survey. The system grows even more complex as one considers its links to other sectors such as manufacture, energy production, and agriculture. The comprehensive view provided by LCA is important if one strives to avoid system sub optimization, such as reducing the impacts of treating the waste at the expense of increased impacts from transportation. A lifecycle perspective can also illustrates the benefits of different waste treatment methods such as the production of heat and electricity from incineration or the production of new raw materials that can replace production from virgin materials.

The aim of the review was to determine whether different studies produced similar results and whether it was possible to identify any key aspects of importance for the results. The results of different studies were strikingly similar and differences could be explained by the key factors identified. Some general findings were:

Incineration with energy recovery saves more energy than landfilling.

Incineration generates less emissions of greenhouse gases than landfilling, with one exception; landfilling of plastics generates less emissions of greenhouse gases, at least in the short-term.

Recycling saves more energy than incineration with one exception; when recycled plastics replace impregnated wood instead of new plastic.

Recycling generally generates less emissions of greenhouse gases than incineration and landfilling, with two exceptions; when recycled plastic does not replace new plastic; and when energy from incineration of paper competes with energy from fossil fuel. In the latter case recycling can lead to either decreased or increased emissions of greenhouse gases, depending on factors such as paper type and the type of fuel used in paper and pulp mills.

Apparently the fate of recycled plastic and the competing fuel to waste are significant for the results. Carlsson (2002) studied how recycled plastic is currently used and found that it generally replaces new plastic. According to Ekvall and Finnveden (2000), the potential competing fuel can be considered in three different time perspectives: 
The current situation with current facilities.

A longer-term perspective, which allows investments and construction of new facilities.

A sustainability perspective.

For the purposes of the present study, the second perspective was the most relevant, because it deals with long-term strategies concerning investments and controls. The third, sustainability perspective is also important to consider, to avoid systems that are not sustainable in the long-term.

Although ineffective from an environmental point of view, combustible materials are still being landfilled. This practice is being phased out in Sweden, but since there is a lack of incineration capacity, this takes time. As a result, in the immediate short-term the competing fuel is in fact other waste that would otherwise be landfilled. Also, if more material can be recycled, more waste will be diverted from landfills while the total amount of incinerated waste will remain constant. In a longer perspective, this will no longer be the case for Swedish waste management, as waste incineration capacity is expected to increase to such an extent that there will be no longer be a lack of incineration capacity (Swedish Government Official Reports, 2005). But looking at the international situation and taking into account the possibility of import and export of waste, there is a risk that waste will continue to be the competing fuel even in the foreseeable future.

In relation to longer time perspectives, Sahlin (2003) discusses the consequences of expanded waste incineration on the energy system. Using questionnaires and computer simulations, Sahlin and colleagues studied the planned expansion of waste incineration and what fuels this expansion would replace. The planned expansion was around 6$7 \mathrm{TWh}$. Heat from waste incineration was expected to replace biofuels (approx. 3.5 TWh), fossil fuel (approx. $1 \mathrm{TWh})$, waste heat $(0.4 \mathrm{TWh})$, heat pumps $(0.4 \mathrm{TWh})$, electricity (approx. 0.5 TWh), and fuels outside the municipal heating system due to the expansion (0.9 TWh). Increased waste incineration would lead to reduced use of and investment in other facilities. As regards investment, waste incineration primarily competes with combustion of biofuels. Increased waste incineration would also lead to a reduced potential for electricity production in power stations.

If, as indicated by the results from Sahlin (2003), waste incineration would primarily compete with biofuels in the medium-term perspective, then increased recycling is favoured from an environmental perspective. In the slightly longer term, it is conceivable that biofuel resources would become limiting and that, e.g., natural gas would be the competing fuel (Nilsson et al., 2002). If resources of biofuels were limited, this could also lead to increased competition between wood pulp and biofuels. If recycling of paper decreases the demand for wood pulp, this means that more biofuels could be extracted to replace natural gas. In such a situation, the outcome would be the same as if biofuels were the competing fuel (Finnveden et al., 2000), hence this case also favours recycling.

In a longer-term sustainability perspective, we will probably not be able to use fossil fuels in the way we do today. Thus, there is reason to believe that renewable energy forms would also be the main competitors for waste in this perspective.

Hence, much suggests that biofuels or other forms of renewable energy would be the primary competitors for waste. This would favour recycling of all types of material. In the medium-term perspective, natural gas is also a possible competing fuel to waste, which would favour incineration of certain paper fractions (Finnveden et al., 2005), but for other types of materials recycling would still be preferred.

The discussion above illustrates one of the benefits of LCA, that it can identify key aspects of the surrounding systems that influences the results, in this case the competing fuels. One may argue that this is not relevant, that the competing fuel should not influence the assessment of waste management systems. However, we argue the opposite. If the consequence of using a certain waste management method is to be assessed, and one consequence is that the use of a competing fuel is changed, then the impacts of this change should be included in the assessment. This approach, to include benefits from avoided fuels, is recommended in the ISO standard for LCA (ISO, 1998).

\subsection{Environmental aspects of choice of fuel}

In a recent consequential LCA, we compared district heating based on household waste incineration with combustion of biomass or natural gas (Eriksson et al., 2007). The study comprises two options for energy recovery (combined heat and power (CHP) or heat only), two alternatives for external, marginal electricity generation (fossil lean or intense), and two alternatives for the alternative waste management (landfill disposal or material recovery). The results indicate that combustion of biofuels in a CHP is environmentally favourable and robust with respect to the avoided type of electricity and waste management. Waste incineration is a good option if it substitutes landfill disposal of waste, but not if it substitutes recycling. A natural gas-fired CHP is a good option if marginal electricity has a high fossil content. However, if the marginal electricity is mainly based on non-fossil sources, natural gas is in general worse than biofuels. Combined heat and power is in generally favourable over heat production only (Eriksson et al., 2007).

\section{Economic aspects}

A number of different economic analyses have been made of the financial advantages and disadvantages of different waste management systems. Carlsson Reich (2003) carried out a review of these analyses and found large 
Table 1

Cost of waste treatment SEK/tonne (Swedish Government Official Reports, 2002) (10 SEK = approx. € 1)

\begin{tabular}{lcc}
\hline Treatment method & $\begin{array}{c}\text { Low } \\
\text { value }\end{array}$ & $\begin{array}{c}\text { High } \\
\text { value }\end{array}$ \\
\hline Incineration & 200 & 700 \\
Biodigestion & 500 & 1700 \\
Composting & 250 & 1000 \\
Landfilling & 100 & 700 \\
Recycling of materials & 50 & 3000 \\
Additional cost of collecting source-separated & 400 & 400 \\
$\quad$ organic waste & & \\
\hline
\end{tabular}

differences between different studies, making it difficult to draw any clear conclusions. Examples of the data used were the following figures from the 2001 Waste Taxation Enquiry (Swedish Government Official Reports, 2002) (Table 1).

As shown in Table 1, the range in cost is large, particularly for recycling of materials due to the different costs for different types of materials.

Different treatment methods have undergone different degrees of technological advancement. Landfilling and incineration are established technologies, while for composting, biodigestion and different types of recycling, there is greater potential for technological improvement. For example, there may be a potential for advantages of scale and increased automatisation within, e.g., plastic recycling (Ny teknik, 2003). Also for incineration there may be possibilities for further technological developments that may result in eco-efficient solutions (Hellweg et al., 2005). However, no major technological jumps are foreseen (Olofsson, 2004).

\section{Behavioural aspects}

A number of studies have been carried out on human behaviour and attitudes to waste management and source separation. A literature review and synthesis was carried out by Sörbom (2003). One of the conclusions of this review was that people are actually willing to source separate waste, although there were some differences between different groups. Another conclusion was that the participation of people in source separation depends strongly on the accessibility of waste separation facilities. Proximity to residences was a key factor in this regard. Ease of sorting was also significant, which indicates that the importance of good information. A third conclusion was that financial incentives could be a way of increasing the willingness of people to source separate waste.

\section{Environmental analysis of waste incineration tax}

In 2002 a Swedish governmental commission assessed the impacts of introducing a tax on incineration of waste, as a complement to the already existing landfill tax (Swedish Government Official Reports, 2002). The environmental consequences of the proposal were mainly evaluated based on previously published analyses. In a separate study we have completed a more in-depth analysis (Björklund et al., 2003; Nilsson et al., 2005) of the no-action alternative as described by the commission, an alternative (1) with a tax on incineration of waste of SEK 400/tonne and two more visionary alternatives $(2 \mathrm{a}, \mathrm{b})$. The no-action alternative reflects the projected waste management in Sweden in 2008 if no waste incineration tax is introduced, but all other means of control are introduced as planned. Alternatives $2 \mathrm{a}$ and $2 \mathrm{~b}$ explore the potential to achieve more farreaching environmental goals than what is achieved by alternative 1 . The design of these two explorative scenarios is based on experience from earlier LCA studies in the field of waste management. The greatest difference in alternatives $2 \mathrm{a}$ and $2 \mathrm{~b}$ compared to the no-action alternative and alternative 1 was high (and uniform) recycling levels of all recyclable materials. The difference between alternatives $2 \mathrm{a}$ and $2 \mathrm{~b}$ was that organic household waste was incinerated in $2 \mathrm{a}$ and treated by biodigestion in $2 \mathrm{~b}$. Incineration of waste was assumed to compete with biofuels.

Results from this study are presented in another paper of this special issue (Björklund and Finnveden, 2007) and only briefly summarised here. For the total energy turnover, all alternatives recover more energy from waste than what is spent on collection and treatment. Alternative 1 produced a small energy gain compared to the no-action alternative but the more visionary alternatives were superior in this aspect. The energy gains in alternative 1 mainly arose from the increased landfill tax in the proposal rather than the introduction of a specific incineration tax, as more materials were recycled at the expense of less landfilling. There was little difference between alternatives $2 \mathrm{a}$ and $2 \mathrm{~b}$, but the total energy gain was somewhat higher when food waste was incinerated in alternative $2 \mathrm{a}$.

For other environmental impacts, the trend was generally similar to that observed for energy turnover, i.e., alternative 1 gave some improvement compared to the no-action alternative, but this improvement was small compared to the potential indicated by the more visionary scenarios.

\section{Geographical aspects}

Since Sweden is a large country with great geographical variation, there may be reason to consider whether different types of waste disposal systems should be used in different regions of the country. In the study on the proposed waste incineration tax (Björklund et al., 2003), we investigated whether differences arose if the waste system was situated in Skåne in the southern more densely populated parts of Sweden, or in a more remote northern part in Norrland. Longer transport distances were assumed in Norrland, and we applied a site-adjusted environmental impact evaluation for some air pollutants. Even though this site-adjusted approach resulted in different estimated environmental impact in the two regions, this did not affect the ranking between alternatives and the general conclusions of the study remained the same as those described above. Thus, 
this study showed no environmental justification for having different policies in different regions of the country.

A conclusion reached by several environmental evaluations of different waste management systems is that once waste has been collected, subsequent transport is of limited importance (c.f. Sundqvist et al., 2002b). However, exceptions can occur in some sparsely populated areas, for example in archipelagos (Eriksson, 2003). On the other hand, transport by private vehicle to and from waste disposal sites can be important for the final outcome (c.f. Finnveden et al., 2000).

Transport can however be important for the economic evaluation. An article by Berglund (2004) presented an economic analysis of optimal corrugated cardboard recycling levels for different Swedish counties, assuming a total material collection level of $65 \%$. The optimal level varied between $51 \%$ and $72 \%$. This difference is not very large, which indicates that approximately similar (if not identical) strategies can be employed in different regions of the country.

\section{Conclusions and discussion}

\subsection{Different strategies}

As a general rule of thumb, recycling of materials such as plastic, paper, metal, glass and other items is preferable from an environmental perspective in all three time perspectives described earlier. Some individual cases for which other alternatives are better, such as the treatment of food waste, wood and other rather pure biofuel fractions, are discussed further below. However, the review of economic aspects indicates that the recycling of materials is often somewhat more expensive than, e.g., incineration, even though uncertainties occur. It is therefore important to consider the cost-effectiveness of recycling.

Waste incineration in Sweden is currently exempt from energy and emission taxes, so that waste as fuel has an economic advantage over other fuels, also giving waste incineration an economic advantage over other treatment methods. This effect can be substantial. If incineration of plastic waste were subject to a carbon dioxide tax at the same level as other fossil fuels, this tax would correspond to more than $3000 \mathrm{SEK} /$ tonne of waste. If such a tax were introduced, the competitiveness of plastic recycling would increase considerably. The proportion of fossil fuel in waste varies, but in household waste it is $\sim 30-40 \%$ of the energy content and $\sim 10-15 \%$ of the weight (RVF, 2003). If waste were subject to energy and carbon dioxide taxes on its fossil fraction, this would correspond to approximately 400-500 SEK/tonne unsorted household waste. This level would also increase the competitiveness of materials recycling. These figures indicate that if waste incineration were subject to the same environmental taxes and fees as other fuels, it would be more expensive, to the benefit of other alternatives. Further, if the potential for technological development and advantages of scale are considered, it is fully possible that recycling can be regarded as equally competitive to incineration.
The review of behavioural studies indicated that people are not only willing, but often eager to source separate waste, provided that the systems in place to do this are accessible and easy to use.

Thus, from the perspective of environmental, economic and social factors, a strategy for waste management could be based on the premise that recycling of materials should be increased.

Sorting of some type is a precondition for treating every fraction in the best possible way. As mentioned above, people are willing to sort waste but at the same time there will always be people who cannot or will not sort. A robust system must therefore be able to deal with unsorted or wrongly sorted waste. Both recycling of materials and biological treatment methods also give rise to waste products, which must be dealt with in some way. Therefore incineration and landfilling have a role to play in an advanced waste management system, i.e., to treat waste fractions that are difficult to dispose of in some other way.

For food waste and other organic fractions, the options are usually incineration, composting, or biodigestion. Environmental analyses indicate that composting has few advantages over biodigestion and incineration. However, these analyses did not consider recycling of micronutrients and the potential increase in soil organic matter content, both of which are advantages of biological treatment. There must however be a market for digestion and compost residues, and organic residues must replace chemical fertiliser for these advantages to make a real impact. This requires pure waste fractions, to produce unpolluted organic residue, which is difficult to achieve for large-scale treatment of wastes from various sources. It is therefore doubtful if such solutions have a role to play in a robust waste strategy. Small-scale solutions, such as household composting or small composting plants in rural areas, or large-scale solutions but with a well-defined homogenous waste input, such as biodigestion of manure or slaughterhouse waste, however have a role to play. In such cases, it is easier to control the waste quality and it is also easier to find a use for the compost end-product.

Any comparison of digestion and incineration is difficult since these methods have rather different advantages and disadvantages and since the environmental effects of digestion depend greatly on a number of options regarding waste fractions, replacement fuel, siting, etc. (c.f. Berglund and Börjesson, 2003; Börjesson and Berglund, 2003). Digestion is pointed out as a good alternative for certain wastes, e.g., manure and certain types of waste from the food industry. Household food waste can be incorporated into the processes as a sub-flow in certain cases (Berglund and Börjesson, 2003; Börjesson and Berglund, 2003).

Incineration has several functions to fulfil in a sustainable waste strategy. Waste flows for which incineration is the most suitable method of disposal include, e.g., wood waste and under some circumstances garden and food waste. In addition, incineration plays a role in the disposal of unsorted waste and of residues from recycling of materials and biological treatments. 
Incineration capacity in Sweden is currently expanding significantly, which is necessary in order to cope with waste that is now being landfilled but that will have to be disposed of in another way in the long-term. However, the question of whether overcapacity of incineration plants is being created arises occasionally. The answer to this question depends on, e.g., future trends in waste volume, the development of other methods of treatment and the development of a commercial trade in wastes. All of these factors are more or less uncertain. There may also be a need for a certain amount of overcapacity to deal with seasonal fluctuations and variations in national economy. It is thus important to construct incineration boilers with maximum flexibility, i.e., they should be able to incinerate other types of solid fuel. It is also appropriate to build in heat and power production capacity to allow flexibility in terms in the products of incineration.

For waste fractions that are neither combustible nor recyclable, landfilling is the only option. Landfilling could be interesting also under other circumstances. For example, landfilling of plastics leads to lower emissions of greenhouse gases compared with incineration, at least in the short term (in this case meaning centuries), which could motivate landfilling of plastic. The release of many other emissions is also postponed, sometimes in an extremely long-term perspective (Moberg et al., 2005).

Simply summarised, the following are good guiding principles for a robust and flexible waste management strategy:

High levels of recycling of materials such as plastics, paper, metal and glass.

Incineration of wastes that can be classified as biofuels. Incineration that allows for both heat and power production and that is able to accept a varied mixture of solid fuels.

Safe landfilling of waste that cannot be treated in any other way and possibly also of non-biodegradable plastics.

Anaerobic digestion of certain well-defined fractions, with low and well-controlled content of hazardous substances.

Easily accessible source separation for consumers.

High levels of source separation in industry.

\subsection{Policy instruments}

Within the waste sector in Sweden, there are a number of different policy instruments. At the same time, it is obvious that there are gaps in the control packages. For example, apart from extended producer responsibility, there is no mechanism to control increased recycling of materials. It is therefore relevant to review such issues.

Our results indicate that an incineration tax would produce environmental benefits. However, there are greater environmental benefits to be gained and there is thus reason to devise control mechanisms that can guide us in those directions. To achieve more sustainable waste management in line with the more visionary scenarios, an incineration tax that differentiates between different waste fractions is a possible alternative. The previous governmental commission on taxation of waste proposed that an exemption be made for types of waste that could be regarded as biofuels. One option may therefore be to extend this exemption to all types of waste of biological origin, e.g., wood, paper and food waste. A charge corresponding to a tax on fossil fuel could then be applied and a rebate given for the proportion of the fuel corresponding to biofuels. Such a tax would steer the system towards increased recycling of the materials for which the environmental benefits are greatest, i.e., non-renewable materials.

A tax directed at incineration of fossil materials in waste would not steer the system towards increased recycling of paper or towards biological treatment of waste. To steer the system in this direction, a weight-based tax might be applicable. Such a tax should be combined with an increase in landfill tax, which would probably produce the benefit of increased recycling of some materials that are currently being landfilled. However, a tax steering the system towards increased biological treatment would primarily increase the use of composting, which according to previous analyses would produce limited environmental benefits compared with biodigestion. It would therefore be good to combine this with control mechanisms promoting biodigestion rather than composting. Subsidising the use of biogas use might be a viable option.

As noted above, combined heat and power is preferential to only heat production. Currently, electricity production from waste incineration is rather low in Sweden. This is because several of the incineration plants lack capacity to produce electricity, and because the electricity price is not always high enough to motivate power generation. In Sweden the current energy taxation system gives high incentives to CHP through by different tax exemptions and reductions. However, since waste is not included in the energy taxation system, this does not apply to electricity production from waste incineration.

A combination of economic control mechanisms that could steer waste management towards attaining national environmental targets could include:

An incineration tax that equalizes taxation of the fossil parts of waste with other fossil fuels and that contains an exemption for wastes of biological origin.

Incentives for electricity production from waste incineration.

A weight-based incineration tax that promotes increased recycling of paper and biological treatment.

A corresponding increase in landfill tax.

A subsidy for biogas use.

Support for the use of recycled materials. 
To increase source separation, economic policy instruments should also exert an effect on consumers. However, these should be combined with information, supporting physical structures (e.g., kerbside/local collection systems) and also with positive economic incentives (e.g., various forms of bonus or refund system). Economic policy instruments should also be directed at various sections of industry, to stimulate their source separation.

The Producer Responsibility Enquiry (Swedish Government Official Reports, 2001) reported that there is a need for increased producer responsibility within a range of different areas. However, the Enquiry did not recognise a need to introduce compulsory producer responsibility since it preferred to await the outcome of a number of voluntary agreements or it did not believe the time was right for other reasons. However, the situation should be reviewed again in the near future to evaluate the effects of the voluntary agreements.

The latest governmental commission on taxation of waste treatment (Swedish Government Official Reports, 2005) proposed some of the suggestions above. They proposed to include the fossil parts of the waste in the energy taxation system. This would give a tax on more than $3000 \mathrm{SEK} /$ tonne waste from fossil sources, corresponding to approx. $450 \mathrm{SEK} /$ tonne mixed municipal solid waste for heat production. This is the maximum level. Different exemptions and reductions are given to combined heat and power production and incineration in industries, e.g., in connection with cement production. The suggestion from the commission was later accepted by the parliament together with a suggested increase of the landfill tax. The commission noted however that the current suggestions may not be enough and that further instruments may be needed. However, they suggested that the new taxes should be implemented and evaluated first, before new policy instruments were introduced.

The conclusions drawn in this study focused on Swedish conditions. However, much of the reviewed literature stems from other countries, but with a fairly strong agreement of results regardless of the country considered. We therefore believe that the results are relevant also for other countries. Furthermore, we have identified some key aspects of relevance to the outcome of the environmental assessments. By considering the situation in a specific country regarding these key aspects, country-specific conclusions may be drawn. We believe however, that often the influence of these country-specific aspects is limited and thus that the strategies and the package of policy instruments suggested here are relevant also for other countries.

\section{Acknowledgement}

Financial support from the Swedish Energy Agency and the Swedish Environmental Protection Agency is gratefully acknowledged.

\section{References}

Åkesson, L., 2004. Rent och orent i sopornas rike (Clean and Unclean in the Kingdom of Waste). In: Formas (2004), 39-48. (In Swedish).

Berglund, C., 2004. Spatial cost efficiency in waste paper handling: the case of corrugated board in Sweden. Resources, Conservation and Recycling 42 (4), 367-387.

Berglund, M., Börjesson, P., 2003. Energianalys av biogassystem (Energy Analysis of Biogas Systems). Report No. 44, Environment and Energy Systems Studies, Lund University, Lund, Sweden. (In Swedish).

Björklund, A., Finnveden, G., 2007. Life Cycle Assessment of a National Policy Proposal - The Case of a Swedish Waste Incineration Tax. Waste Management (this issue).

Björklund, A., Finnveden, G., 2005. Recycling revisited - life cycle comparisons of waste management strategies. Resources, Conservation and Recycling 44, 309-317.

Björklund, A. Johansson, J., Nilsson, M., Eldh, P., Finnveden, G., 2003. Environmental assessment of a waste incineration tax, a case study and evaluation of a framework for strategic environmental assessment. Fms Report 184, Environmental Strategies Research Group - fms, Stockholm, Sweden.

Börjesson, P., Berglund, M., 2003. Miljöanalys av biogassystem (environmental analysis of biogas systems). Report No. 45, Environment and Energy Systems Stsudies, Lund University, Lund, Sweden. (In Swedish).

Carlsson Reich, M., 2003. Syntes av studier på ekonomiska för-och nackdelar med olika avfallshanteringsstrategier (Synthesis of Studies on the Pros and Cons of Different Waste Management Strategies). Fms-report 186, Environmental Strategies Research Group - fms, Stockholm, Sweden

Carlsson, A.-S., 2002. Kartläggning och utvärdering av plaståtervinning i ORWARE (Survey and Assessment of Plastics Recycling in ORWARE. IVL Report B1418, IVL Swedish Environmental Research Institute, Stockholm, Sweden. (In Swedish)

Ekvall, T., Finnveden, G., 2000. the application of life cycle assessment to integrated solid waste management, Part II - Perspectives on energy and material recovery from paper. Trans IchemE 78, part B, 288-294.

Eriksson, O., 2003. Environmental and economic assessment of swedish municipal solid waste management in a systems perspective. PhD Thesis, Industrial Ecology, Royal Institute of Technology, Stockholm, Sweden.

Eriksson, O., 2004. Hållbar fjärrvärme. Fjärrvärme i ett ekologiskt hållbarhetsperspektiv (sustainable district heating). Report 2004:4, The Swedish District Heating Association, Stockholm, Sweden. (In Swedish).

Eriksson, O., Finnveden, G., Ekvall, T., Björklund, A., 2007. Life cycle assessment of fuels for district heating. A comparison of waste incineration, biomass and natural gas combustion. Energy Policy 35, $1346-1362$.

Finnveden, G., Ekvall, T., 1998. Life cycle assessment as a decisionsupport tool - the case of recycling vs. incineration of paper. Resources, Conservation and Recycling 24, 235-256.

Finnveden, G., Johansson, J., Lind, P., Moberg, Å., 2000. Life cycle assessment of energy from solid waste. Fms-report 2000:2, Environmental Strategies Research Group - fms, Stockholm, Sweden.

Finnveden, G., Johansson, J., Lind, P., Moberg, A., 2005. Life cycle assessment of energy from solid waste - part 1: general methodology and results. Journal of Cleaner Production 13, 213-229.

Formas, 2004. Sopor hit och dit - på vinst och förlust (Waste To and Fro - A Gamble). In: Formas Fokuserar, The Swedish Research Council Formas. Stockholm, Sweden. (In Swedish).

Hellweg, S., Doka, G., Finnveden, G., Hungerbühler, K., 2005. Assessing the eco-efficiency of end-of-pipe technologies with the environmental cost efficiency indicator: a case study of solid waste management. Journal of Industrial Ecology 9 (4), 189-203.

ISO, 1998. Life cycle inventory analysis. ISO standard 14041, International Organization for Standardization. 
Moberg, Å., Finnveden, G., Johansson, J., Lind, P., 2005. Life cycle assessment of energy from solid waste - part 2: landfilling compared to other treatment methods. Journal of Cleaner Production 13, 231-240.

Nilsson, M., Finnveden, G., Johansson, J., Moberg, Å., 2002. Strategic environmental assessment of natural gas grid extensions. Report 5240, Swedish Environmental Protection Agency, Stockholm, Sweden.

Nilsson, M., Björklund, A., Finnveden, G., Johansson, J., 2005. Testing an SEA methodology for the energy sector - a waste incineration tax proposal. Environmental Impact Assessment Review 25, 1-32.

Ny teknik, 2003. Lortig hantering av plastsopor (Dirty Handling of Plastic Waste). Ny teknik, September 17, 2003.

Olofsson, M., 2004. Improving model-based systems analysis of waste management. PhD Thesis, Chalmers University of Technology, Göteborg, Sweden.

Palm, V., Looström Urban, H., Wadeskog, A., Finnveden, G., Moberg, Å., 2002. Kunskap om produkters miljöpåverkan - vad ger dagens statistik? (knowledge about the environmental impact of products what does today's statistics tell us?) Report 5231, Swedish Environmental Protection Agency, Stockholm, Sweden. (In Swedish).

Profu, 2004. Evaluating waste incineration as treatment and energy recovery method from an environmental point of view. Profu AB, Mölndal, Sweden.

RVF, 2003. Förbränning av avfall. Utsläpp av växthusgaser jämfört med annan avfallsbehandling och annan energiproduktion (incineration of waste. emissions of greenhouse gases compared to other waste treatment and other energy production). RVF Report 2003:12, RVF - The Swedish Association of Waste Management, Malmö, Sweden. (In Swedish).
Sahlin, J., 2003. Waste Incineration - Future Role in the Swedish District Heating System. Department of Energy Conversion, Chalmers University of Technology, Göteborg, Sweden.

Sundqvist, J.-O., Finnveden, G., Sundberg, J. (Eds.), 2002a. Proceedings from Workshop on System Studies of Integrated Solid Waste Management in Stockholm 2-3 April 2001. IVL Report B1490, IVL Swedish Environmental Research Istitute, Stockholm, Sweden.

Sundqvist, J.-O., Finnveden, G. och Sundberg, J. (eds.), 2002b. Syntes av systemanalyser av avfallshantering (synthesis of systems analyses of waste management. IVL Report B1491, IVL Swedish Environmental Research Istitute, Stockholm, Sweden. (In Swedish).

Swedish Government Official Reports, 2001. Resurs i retur. Betänkande från Utredningen för översyn av producentansvaret (Resources in Return). SOU 2001:102. (In Swedish).

Swedish Government Official Reports, 2002, Skatt på avfall idag - och i framtiden (A Waste Tax Today - and in the Future). SOU 2002:9. (In Swedish).

Swedish Government Official Reports, 2005. En bra skatt? - beskattning av avfall som förbränns. Delbetänkande från BRAS-utredningen (A Good Tax? - Imposing a Tax on Waste that is Incinerated). SOU 2005:23, Stockholm, Sweden. (In Swedish).

Sörbom, A., 2003. Den som kan - sorterar mer! Några slutsatser baserade på tidigare forskning kring källsortering i hushållen (The One Who Can - Will Sort More! Some Conclusions Based on Earlier Research on Source Separation in Households). Fms report 180, Environmental Strategies Research Group - fms, Stockholm, Sweden. 